\title{
»Nu blir ju alla pingisälskare arga.» \\ Humor, makt och kön i studiosamtal om längdskidor
}

\author{
Av HANNA SÖDERLUND
}

\begin{abstract}
Söderlund, Hanna, hanna.soderlund@umu.se, Ph.D., Department of Language Studies, Umeå University: " 'Now all ping pong lovers will become angry.' Humour, power and gender in studio conversations about cross-country skiing”. Språk och stil NF 30, pp 205-234.

Humour is a means of negotiating for power positions in conversations. In conversations on TV, these negotiations reach a large audience. The aim of this study is to investigate how power positions and gender are negotiated for through the use of humour by female and male sport pundits and commentators. How does the host interact with the sport pundits in a comical discourse? What response do sport pundits receive when interacting in a comical discourse? In my analysis, I investigate to what extent social closeness and distance affect both the outcome of how humour is generated and which power positions are achieved. The method employed in this article is discourse analysis in combination with conversation analysis, and the material comes from the World Championship in cross-country skiing 2017, broadcast on Swedish public service TV (SVT). The results show that humour gives somewhat different outcomes between different interlocutors depending on gender. The male expert and commentators achieve powerful positions and social closeness in the comical discourse when interacting with the host. The female expert is not able to achieve powerful positions in the same way, due to the different responses she receives in the comical discourse. This also creates a social distance between her and the others. The asymmetry in how different interlocutors are treated is also a part of how notions of gender are (re)produced in a comical discourse.
\end{abstract}

Keywords: power relations, gender, conversation analysis, television discourse, humour, discourse analysis.

I den här artikeln undersöks hur makt förhandlas fram genom att man använder humor i samtal om skidsport på tv. Några generella mönster för vem som kan uppfattas som rolig och vem som kan uppfattas som kompetent lyfts fram i denna fallstudie. Den humor som används kan ge upphov till social närhet eller distans samtalsdeltagarna emellan, vilket också diskuteras i artikeln. Materialet för studien är SVT:s sändningar från VM i längdskidor i Lahtis 2017. Många kan ta del av det som visas på tv, vilket gör att tv har stor genomslagskraft. Me-

Stöd till projektet har erhållits från Centrum för idrottsforskning.

https://doi.org/10.33063/diva-427680 
dierna har därför en stor institutionell makt när det gäller vilka ideologier som kommer fram och hur vi ska förstå världen (Messner 2007 s. 124).

I samtal har alla som deltar möjligheter att uppnå starka maktpositioner, enligt Foucaults sätt att se på makt (Foucault 1993). Individer i samtal kan själva skapa sina förutsättningar, men behöver för att lyckas också stöd från andra som de interagerar med. I ett studiosamtal på tv har programledaren en institutionell maktposition i egenskap av den som styr samtalen, vilket gör att den personen i stor utsträckning bidrar till andras möjligheter att uppnå starka maktpositioner. I den här fallstudien av ett urval program synliggörs vissa maktrelationer som förhandlas fram lokalt. Även om förhandlingarna är lokala kan de också säga något om övergripande maktstrukturer (exempelvis sociokulturella).

I materialet undersöks både en övergripande idrottslig diskurs och en komisk diskurs i relation till makt och kön. Syftet är att undersöka hur föreställningar om kön (re)produceras. Studien sker genom att jag kartlägger vilka maktpositioner skidexperter och skidkommentatorer på tv kan förhandla fram när de använder humor. Därutöver diskuteras hur social närhet och distans uppstår genom hur förhandlingarna av makt sker. De forskningsfrågor som ställs är:

- Hur interagerar programledaren med kvinnliga och manliga experter och kommentatorer i en komisk diskurs?

- Vilken respons får kvinnliga och manliga experter och kommentatorer som interagerar i en komisk diskurs?

\section{Idrott och kön}

I den här studien ligger fokus på idrott som konsumeras via tv som underhållning. Även om det är studiosamtal som undersöks belyses nedan några hegemoniska maktrelationer som finns inom olika idrottsliga diskurser.

Historiskt har idrott varit ett viktigt om än problematiskt område för grundläggande sociala föreställningar om maskulinitet och femininitet, enligt Michael A. Messner (2007). Därmed har den blivit en arena för ideologisk kamp när det gäller maktrelationer mellan kvinnor och män (s. 34). Idrott har kommit att bli ett område som domineras av män, inte minst för att de högre maktpositionerna $\mathrm{i}$ idrottsvärlden oftare innehas av män, enligt Gertrude Pfister (2010 s. 242). 
Hegemoniska maktrelationer och föreställningar om kön förhandlas fram på subtila sätt, exempelvis genom mediala representationer av kön. Dessa representationer spelar en viktig roll för konstruktionen av femininitet och maskulinitet. Pirkko Markula (2009) menar att kvinnliga idrottare inte är kvantitativt representerade i medierna i samma utsträckning som manliga. På så vis bidrar medier till att idrottande kvinnor framstår som mindre intressanta än idrottande män (s. 6). Helena Tolvhed (2008), som undersökt hur svenska idrottares prestationer under OS beskrivs i veckotidningar under mitten av 1900-talet, kommer också fram till att kvinnliga och manliga idrottare porträtteras på olika sätt. Män framställs exempelvis som fysiskt hårda (s. 98) och kvinnor som fysiskt attraktiva (s. 170). Tolvhed kommer även fram till att tävlingsidrotten ofta ses som nationalistisk, där den egna nationens framgångar premieras. Det är alltid bra om svenska idrottare lyckas, men dåligt om de misslyckas (s. 88).

SVT:s sportredaktion har de senaste åren gjort genomgångar av hur många timmar idrott de sänder som porträtterar kvinnor respektive män, i syfte att uppskatta hur jämställda deras sportsändningar är. Sportchefen på SVT har sedan kommenterat jämställdheten i blogginlägg på SVT Sport. Under 2016 handlade knappt vart tredje inslag om damidrott i deras nyhetsprogram Sportnytt och Sportspegeln, medan två tredjedelar således gällde herridrott (Jönsson 2018). Året därpå hade damidrotten ökat till 38 procent och herridrotten minskat till 62 procent (ibid.). Under 2018, då även svtsport.se inkluderades i genomgången, hade rapporteringen av damidrott landat på 44 procent och herridrotten på 56 procent (Jönsson 2019) vilket författaren menar visar att sändningarna blivit mer jämställda. Messner (2007) anser att alla medierapporteringar ska ses som ideologiska konstruktioner. Det är medierna själva som bestämmer vad som ska uppmärksammas, betonas, ignoreras eller marginaliseras (s. 124).

Även journalistiskt har idrotten dominerats av män, vilket har gjort det svårt för kvinnliga journalister att ta sig in, enligt Pfister (2010 s. 240). Stina Branting (2016) har intervjuat kvinnliga idrottsjournalister som menar att de återkommande möts av negativa attityder baserat på kön.

\section{Humor, maktpositioner och kön}

Nedan diskuteras inledningsvis studier och teorier som handlar om humor och skratt i olika typer av samtal. Därefter beskrivs studier som undersökt relatio- 
nen mellan humor och kön. Avslutningsvis redogörs för studier som behandlar hur maktpositioner förhandlas fram i offentliga, företrädesvis i mediala, sammanhang, men också i andra.

\subsection{Humorns funktioner i samtal}

Humor kan ha olika funktioner i samtal. Wallace Chafe (1987) menar att humor är »the safety valve that saves us from the consequences of our natural reasoning when it would get us into trouble» (s. 18). Humor kan alltså ses vara en räddning för att vi ska kunna ta oss ur olika situationer.

I samtal mellan vänner beskriver Jennifer Hay (1995 s. 97-98) hur humor kan ha tre övergripande funktioner, utifrån en uppställning som bygger på makt, solidaritet och psykologi. Humor kan användas för att betona maktskillnader, exempelvis genom att en person retar andra i syfte att få en bättre maktposition. Solidaritet kan skapas genom att man närmar sig andra och delar erfarenheter, men också genom att man retas på ett sätt som skapar social närhet. Psykologiskt kan humor användas för att hantera olika situationer: man kan försöka försvara sig mot andra, förekomma kritik eller hantera sådant som uppstår i samtal (Hay 2000 s. 717). Humor kan således vara ett sätt för människor att försöka närma sig eller att distansera sig från andra (Davies 2017 s. 482).

Maktrelationer eller hierarkier kan också synliggöras genom vem man skämtar om och hur. Att använda humor som gör personer med en stark maktposition till måltavla behöver inte vara förknippat med tabu, vilket politisk satir är ett exempel på (Billig 2005 s. 208). Det är också därför elever kan skämta om sina lärare och vuxna om sina chefer (Purdie 1993 s. 65). Det går att skämta om människor med makt eller sociala grupper som är hegemoniska, eftersom det kan vara ett sätt att försöka utmana maktordningar. Däremot kan det uppfattas som stötande att skämta om olika sociala grupper som ses som ickehegemoniska, eftersom det kan uppfattas som exempelvis rasistiskt (Billig 2009), men även sexistiskt eller funkofobiskt.

\subsection{Skratt i samtal}

Oavsett sammanhang är skrattet som respons viktigt i humor, och även skrattet fyller olika funktioner. Skratt ses ofta som slutklämmen på ett skämt och det som gör skämtet framgångsrikt, enligt Harvey Sacks (1974). Sacks menar samtidigt att mottagare av ett skämt inte måste skratta. Det innebär att såväl förse- 
nat skratt som tystnad är möjliga avslut på ett skämt (s. 347 f.). Neal R. Norrick (1993 s. 23) hävdar dock att skratt kan ses som den andra delen i ett närhetspar, vilket skulle innebära att det är den respons som är förväntad. Avsaknad av skratt eller tystnad kan därför ses som att turtagningen i samtalet saknar något. Att mottagaren inte skrattar kan ha att göra med skämtets lämplighet i kontexten eller att mottagaren inte förstår skämtet. Men att inte skratta kan också ses som att det fyller en funktion. Att inte skratta är aggressivt, ett sätt att utöva makt. Michael Billig menar därför att frånvaro av skratt ska ses retoriskt (2005 s. 192).

I en forskningsgenomgång av humorns sociala funktioner beskriver Jürgen Trouvain och Khiet P. Truong (2017) hur skratt kan skapa social närhet samtidigt som det bidrar till en god stämning. På samma sätt menar de att avsaknaden av skratt kan skapa ett socialt avstånd (s. 342). Social närhet mellan två som skämtar kan därmed uppstå först när den man skämtar inför också visar sin uppskattning av skämtet (se även Tsakona 2017 s. 4). Helga Kotthoff menar att risken för att ingen ska skratta åt ens skämt är förknippad med stor skräck och skam, vilket kan vara en anledning till att försiktiga personer, främlingar eller människor med låg status undviker att skämta i olika sammanhang (2006 s. 8). En viktig aspekt är dock att skratt inte behöver vara ett tecken på god vilja och acceptans (Kotthoff 1996 s. 320).

Viveka Adelswärd har undersökt institutionella samtal (bl.a. arbetsintervjuer och telefonsamtal mellan Socialstyrelsen och föräldrar). Hon beskriver hur skratt är socialt konstruerat och kan ha olika funktioner: en modifierande funktion för att visa hur ett yttrande ska tolkas, funktionen av att bevara eller skapa status samt funktionen av att hantera ansiktshot (Adelswärd 1989 s. 129). I sin studie av arbetsintervjuer ser Adelswärd (1995) att skrattet kan visa på gemenskap. Intervjuarna i studien skrattar mer tillsammans med de sökande som de senare också rekommenderar att anställa (s. 133). Man kan fundera över om resultaten visar att man väljer att skapa en bra atmosfär tillsammans med personer som man tror sig vilja anställa, eller om det är så att man i större utsträckning beslutar sig för att anställa personer där social närhet uppstått genom skratt.

Även om såväl skratt som humor kan ha fler funktioner i samtal kan det ändå i stor utsträckning ses som något som kan skapa gemenskap när det handlar om humor i grupper med ett gemensamt mål. I studioprogrammen om skidsport på SVT är det gemensamma syftet att analysera skidåkning och samtidigt underhålla en tv-publik. I den andan bör god stämning vara något som man vill uppnå i programmet. 


\section{Hanna Söderlund}

\subsection{Studier av humor och kön}

Humordiskurser kan ibland uppfattas som manligt dominerade, exempelvis genom vem som anses vara humoristisk. I en studie av Maria Ohlsson (2003) har studenter fått fylla i en enkät där de namngett någon de uppfattar som humoristisk. I enkäten framkommer att män oftare uppfattas som humoristiska i offentliga sammanhang. I privata sammanhang är majoriteten inte lika stor för männen, utan det kan oftare också vara kvinnor. Dock är det främst kvinnor som uppger att de uppfattar andra kvinnor som humoristiska (s. 341).

I vängrupper kan dynamiken i humor se olika ut i beroende på om gruppen innehåller både kvinnor och män eller om den är enkönad. Martin D. Lampert och Susan M. Ervin-Tripp upptäckte i sin studie att män i könsmixade grupper retas mindre med andra och skämtar mer om sig själva, medan kvinnor i könsmixade grupper skämtar mindre självutlämnande och istället mer retsamt med män (2006 s. 69). Män tenderar också att undvika att reta kvinnliga vänner i könsmixade grupper eftersom beteendet kan uppfattas som aggressivt då det riktas mot kvinnor, enligt författarna. Männens strategi kan vara att försöka skapa och upprätthålla symmetriska maktrelationer inom gruppen (s. 66). Författarna menar att kvinnorna inte uppskattar att bli retade av män. Det framgår dock inte om det främst är baserat på kulturella föreställningar om kön, eller vad kvinnor och män faktiskt upplever. Männens modifierade beteende i könsmixade grupper kan betraktas som respektstrategier.

I studier som undersökt maktpositioner och humor har man också upptäckt att när kvinnor har svårt att nå en stark maktposition använder de humor för att kunna vända på maktförhållanden. Den strategin använder kvinnliga komiker som inte făr tillträde till golvet i humorprogrammet Parlamentet, enligt min avhandlingsstudie (Söderlund 2016 s. 184). Även Britt-Louise Gunnarsson som har studerat doktorander i seminariemiljöer ser liknande beteenden (2002). Hon menar att kvinnliga doktorander som möts av motstånd kan förändra maktordningar genom att använda humor (s. 259).

Humor kan på olika sätt vara ett iscensättande av kön. Enligt Jennifer Coates iscensätts femininitet genom att man använder humor som självförsvar medan maskulinitet oftare iscensätts genom att man förolämpar varandra eller ägnar sig åt verbala dueller (2014 s. 163). Verbala dueller och utmanande tilltal är också något som elever på fordonsprogrammet använder som ett sätt att iscensätta maskulinitet och skapa hierarkier enligt en studie av Katarina Kärnebro (2013 s. 298). Även i samtal i tv-dokumentärer förhandlas maskulinitet fram 
genom att män retas aggressivt och skämtar nedsättande med varandra (Chovanec 2017 s. 46).

\subsection{Maktpositioner i offentligheten}

Många av de studier där makt i offentligheten undersökts, visar på att den som leder samtalen har en avgörande roll.

Mats Nylund (2000) har i sin avhandling undersökt interaktion i politiska debatter och intervjuprogram i direktsänd tv och radio. Han menar att den som leder samtalen (t.ex. en programledare) i studiosammanhang har makt över vem som kan komma till tals under samtalen, men också vem som kan framstå som engagerad eller kompetent i ett givet samtalsämne (s. 238). I radiosamtal i brittisk kontext där personer ringer in till en programledare, noterar Ian Hutchby (2006) att stor makt ligger på programledaren i kraft av hur turtagningen sker. Programledaren är i position att kunna underminera inringarens argument utan att behöva framföra egna (s. 100).

Programledaren har en viktig roll också när det handlar om att få andra att framstå som humoristiska. Brett Mills har undersökt det brittiska frågeprogrammet $Q I$, och kommit fram till att det i stor utsträckning är programledaren som avgör vem som kan framstå som kunnig eller humoristisk i en kunskapsorienterad diskurs (2011 s. 140). En av Mills slutsatser är att de manliga deltagarna gynnas av programledarens agerande och av de tävlingsinriktade formerna av skämtteknik. Dessutom är de kvinnliga deltagarna i QI generellt sett i minoritet; de är aldrig fler än en av fyra. En ständig manlig deltagare har rollen som whipping boy (s. 144). Rollen innebär att han alltid är måltavla för skämtande eller på andra sätt görs låg sett till makt. Trots att maktpositionen kan anses låg, medför den samtidigt att han får en humoristisk position.

Forskning i svensk kontext visar också på asymmetrier som uppstår utifrån kön i humordiskurser. I tv-programmet Parlamentet behandlas de kvinnliga och manliga komikerna på lite olika sätt enligt min avhandlingsstudie (Söderlund 2016). Förutom att de kvinnliga komikerna i programmet totalt sett är färre till antalet, har de också svårare att få tillgång till utrymme trots att de försöker. De manliga komikerna blir bekräftade i större utsträckning och de kvinnliga komikerna blir avvisade i större utsträckning, båda av moderatorn och av de andra komikerna. Asymmetrin i beteendet gör att de kvinnliga komikerna i slutändan har svårare att uppfattas som humoristiska än de manliga komikerna (s. 186). 


\section{Hanna Söderlund}

Skillnader i bemötande kan även skönjas i politiska debatter. Kirsten Gomard (2001) som har undersökt politiska debatter i dansk tv menar att det finns asymmetri i hur kvinnliga och manliga politiker blir behandlade. Kvinnorna i hennes studie ges mindre utrymme och har sämre möjligheter att uppnå starka maktpositioner. Detta sker genom både programledarens och ibland de egna partikamraternas agerande (s. 89-91).

I tysk kontext har Helga Kotthoff (1997) undersökt gruppdiskussioner i ett tv-program för att analysera hur makt förhandlas fram i samtalen. Kotthoff menar att den som både presenterar sig som expert och får bekräftelse i interaktion blir den som också kan uppnå expertpositionen (s. 140). Det som ger hög status är att få frågor och samtalsstöd av andra, prata mycket, definiera ämnen, föra fram egna åsikter som viktiga och samtidigt framgångsrikt skämta bort andras. Företrädesvis är det män i studien som framgångsrikt kan uppnå positionen som expert. Kotthoff belyser genom sin studie att kön är en faktor som kan bidra till att forma maktasymmetri i samtal (s. 144).

Maria Edström (2001) har undersökt representationer av kön på tv genom att analysera olika tv-program. Hon menar att synen vi har på kön bekräftas, utmanas och omförhandlas genom de många olika sätt som kvinnor och män representeras på och att det bidrar till att det medierna förmedlar också sätter gränser för hur vi ser på personer baserat på kön (s. 93).

\section{Material och urval}

Materialet till den här studien består av studiosamtalen i SVT:s sändningar från VM i längdskidor, Lahtis 2017. Anledningen till att valet fallit på just längdskidor är att sporten ses som förhållandevis jämställd, där kvinnliga och manliga idrottare har liknande förutsättningar och där de dessutom tävlar på i princip samma banor under samma mästerskap och med samma prispengar. Mästerskapet utgör också en avgränsad mängd material för en fallstudie. Studiosamtalen är relevanta att undersöka utifrån förhandlingar av makt eftersom de är flerpartssamtal. Dessa har delvis en annan dynamik än dyader, inte minst eftersom det då finns en person som kan utgöra publik till två som skämtar. Experterna får också mycket fokus eftersom de under studiosamtalen är i bild under en stor del av samtalstiden, till skillnad från exempelvis kommentatorerna som under skidloppen aldrig syns i bild.

VM sändes under dagarna 23 februari-5 mars 2017. Studiosamtalen och 
kommenteringen av skidloppen sker på plats i Lahtis. Under VM:s helgsändningar kallas hela programmet Vinterstudion ${ }^{1}$ och inkluderar då även annan sport. Mitt urval utgörs dock endast av de studiosamtal som handlar om längdskidor och då endast de studiosamtal som sker före och efter skidloppen. Totalt rör det sig om 26 studiosamtal.

Programledare för studiosamtalen är André Pops, som sedan 2007 varit med och lett Vinterstudion. De experter som sitter med i studion under samtalen är Johanna Ojala, tränare och tidigare elitskidåkare, och Mathias Fredriksson, tidigare landslagsåkare. De två som kommenterar skidloppen i SVT under sändningarna är journalisten Jacob Hård och skidexperten och tidigare landslagsåkaren Anders Blomquist, vilka också bjuds in i samtalen via infälld bild i några av studiosamtalen. I transkriptioner och analys används $p l$ för programledaren samt experternas och kommentatorernas respektive förnamn.

Studiosamtalen i SVT är specifika till sin karaktär av två anledningar. Den första är att samtalen har dubbla syften. De är både arbetsrelaterade möten med krav på att vara kontextbundna med fokus på en uppgift (jfr Holmes 2000 s. 37) och tv-sänd underhållning skapad för att underhålla en tv-publik (jfr Mullany 2002 s. 7). Den andra anledningen är att samtalen i stor utsträckning bygger på närhetspar där programledaren ställer frågor eller kommer med kommentarer som experterna sedan besvarar.

Av de 26 studiosändningarna har sju valts ut för analys (se materialförteckningen). Urvalet av studiosamtal är gjort utifrån att de innehåller interaktion $\mathrm{i}$ en komisk diskurs, att båda experterna i större utsträckning befinner sig i studion, att samtalen fördelar sig lika mellan att handla om dam- och herrlopp samt att de är spridda över hela VM. Allt som sker utanför studiosamtalen, exempelvis intervjuer, presskonferenser, reportage och när man visar annan sport, ligger utom analys. Studiosamtalen varierar i längd, från 15 minuter till strax över timmen. Den totala sändningstiden i urvalet är ca 4 timmar och 40 minuter. Under den tiden initieras totalt interaktion i en komisk diskurs vid 33 tillfällen, främst av programledaren. I den här artikeln presenteras fem av dessa interaktioner, i form av kortare samtalssekvenser. Urvalet av sekvenser illustrerar generella mönster i två avseenden: Det ena mönstret handlar om vilka maktpositioner samtalsdeltagarna kan förhandla fram. Det andra handlar om huruvida skämtandet bidrar till att skapa social närhet eller distans samtalsdeltagarna emellan.

${ }^{1}$ Ett studioprogram i SVT som på helgerna under vinterhalvåret ramar in olika, framför allt, vintersporter. 


\section{Hanna Söderlund}

\section{Teori och metod}

Mitt syfte är att studera hur maktpositioner förhandlas fram i det empiriska materialet. Studien har inspirerats av feministisk poststrukturalistisk diskursanalys (FPDA), med samtalsanalys i vid bemärkelse som metod. Den exakta metoden för analysen är dock utvecklad under arbetets gång, vilket innebär att presentationen också bör ses som en metodutveckling. I följande avsnitt beskrivs metoden utifrån följande: diskurs, makt och kön, ansiktsrelaterat arbete, diskurser i studiosamtalen, samtalsanalys i vid bemärkelse samt maktpositioner kopplade till social närhet eller distans.

\subsection{FPDA: diskurs, makt och kön}

I studien innebär diskurs att praktiker är organiserade på ett sådant sätt att de skapar en samsyn runt kunskaper vi har om världen (se Foucault 1989 s. 49). Inom FPDA menar man att makt förhandlas fram genom interaktion i diskurser som kan både överlappa varandra och vara motsägelsefulla (Baxter 2003 s. 1). Det innebär i praktiken att olika diskurser undersöks, och att en maktposition kan förefalla stark i en diskurs men svag i en annan. Makt förhandlas fram i alla typer av samtal genom hur människor interagerar med varandra. Det kan exempelvis visa sig genom hur man skämtar med någon och responsen den andra personen ger. En stark maktposition är således inget en person har utan något som hen kan få tillträde till eller avvisas från i interaktion. Makt är därmed något som är under ständig omförhandling mellan människor (Foucault 1993).

Makt förhandlas fram lokalt. Men övergripande maktstrukturer (exempelvis sociokulturella) kan bidra till att vissa personer har större möjlighet att förhandla sig till starka maktpositioner än andra. I de lokala förhandlingarna kan personliga relationer och humör också vara faktorer som spelar in (Kotthoff 2006 s. 8). De lokala förhandlingarna kan både påverka och påverkas av övergripande föreställningar och maktstrukturer, vilket är ett synsätt som kommer från Norman Faircloughs kritiska diskursanalys. Synsättet innebär att det råder ett dialektiskt förhållande mellan vad vi gör i interaktion, alltså den diskursiva praktiken, och föreställningar som finns på ett samhälleligt plan (Fairclough 2001 s. 30-31), till exempel föreställningar som finns om kön. Interaktion som sker offentligt via exempelvis tv kan antingen utmana eller reproducera olika maktordningar och föreställningar som finns. Eftersom tv-sändningarna har många tittare får de också stort genomslag. De maktordningar som förhandlas 
fram där kan således få återverkningar inom andra diskurser och på andra arenor.

I den här undersökningen kopplas förhandlingar av makt också samman med förhandlingar av kön. Kön ses som en del av en social identitet, något som hela tiden iscensätts (Butler 2007). Även kön är alltså något som är under ständig förhandling i interaktion. Även om det är möjligt att iscensätta kön på många olika sätt i olika diskurser så kan man säga att ramen för vad som är lämpligt eller ens möjligt ofta är snäv. Judith Butler talar om en rigid regulativ struktur inom vilken föreställningar om kön görs begriplig (2007 s. 88). Strukturen innebär att det finns föreställningar om hur människor ska bete sig baserade på vilket kön de identifierar sig som. En kulturell föreställning som finns om kön är exempelvis att kvinnor förväntas vara mer försonande och stödjande i samtal medan män förväntas ha en samtalsstil som är mer konfronterande och direkt (Holmes \& Stubbe 2003 s. 574). ${ }^{2}$

\subsection{Ansiktsrelaterat arbete}

I analysen diskuteras strategier som kan kopplas till det sociala ansiktet, ett begrepp som kommer från Ervin Goffmans face (2005 s. 5). För att bevara vårt eget och andras sociala ansikte ägnar vi oss åt ansiktsrelaterat arbete. Ibland kan vi utsättas för ansiktshot som gör att vi riskerar att tappa vårt sociala ansikte. Att uttrycka meningsskiljaktigheter är ett exempel på ett potentiellt ansiktshot. Därför lindas meningsskiljaktigheter ofta in när de uttrycks. Ett sätt att linda in ett budskap är att använda humor, eller att rama in ett uttalande som humoristiskt (Adelswärd 1989 s. 129).

Det sociala ansiktet beskriver Håkan Landqvist »som något som konstrueras och hanteras gemensamt av båda parter i samtalet» (2001 s. 21). Penelope Brown och Stephen Levinson argumenterar för att olika parter i ett samtal ständigt beräknar maktskillnader sinsemellan - vilken social distans de har till varandra och hur mycket ett specifikt uttalande kan hota någon annan socialt (1987 s. 74). I den här studien diskuteras främst skämtande som innehållsligt kan uppfattas som ansiktshotande.

Det ansiktsrelaterade arbetet kan betona solidaritet/närhet eller respekt/distans, vilket realiseras genom övergripande attityder och språkhandlingar i interaktion. Närhet kan skapas genom skratt, skämtande och samtalsstöd (Norrby 2014 s. 220). Men det kan också visa sig genom att saker kan uttryckas implicit

\footnotetext{
${ }^{2}$ I analysen baseras kön på hur jag uppfattar att individerna själva identifierar sig.
} 


\section{Hanna Söderlund}

eller mer direkt, eftersom personer som känner varandra kan ha ett mer direkt tilltal utan att det blir ansiktshotande (Brown \& Levinson 1987 s. 72). Respektstrategier innebär i stället att behålla social distans, vilket kan manifesteras genom att man använder indirekta språkhandlingar i syfte att minska potentiella ansiktshot. Norrby anger garderingar och att linda in budskap som exempel på detta (2014 s. 224). Närhet och distans i studien relaterar till hur makt och kön förhandlas fram, vilket diskuteras vidare längre fram.

\subsection{Diskurser i studiosamtalen}

Vem som kan få tillgång till en stark maktposition i studiosamtalen undersöks genom att jag kartlägger hur man skämtar med varandra samt vilken respons som ges i en komisk diskurs. Studiosamtalen kan till stor del sägas befinna sig i en övergripande idrottslig diskurs eftersom det främst är idrott (specifikt längdskidor) som diskuteras. Den idrottsliga diskursen är central för samtalen, och samtidigt den diskurs som tv-tittarna förväntar sig att möta när de ser programmet. I den här studien är det humor som undersöks, och därför innehåller alla exempel interaktion som sker i en komisk diskurs. Den komiska diskursen initieras alltså när någon säger något skämtsamt. Definitionen av skämtande som jag har gjort är: allt som kan uppfattas som humoristiskt utifrån absurditet eller hur saker verkligen förhåller sig, ironi/tonalitet och vad samtalsdeltagarna själva har tolkat som humor (en tolkning jag baserar på respons). Allt sådant som alltså kan uppfattas som humor och som behandlas humoristiskt menar jag är interaktion som sker i en komisk diskurs. Även om skratt inte måste vara en respons på något komiskt, menar jag att skratt och leenden kan skapa en inramning av komik. Att skratta kan vara ett sätt att visa hur något ska tolkas, eller användas för att mildra något som annars kan uppfattas som ett ansiktshot (Adelswärd 1989 s. 129). Skratt kan också användas för att lätta upp stämningen. Jag beskriver tolkningen av den komiska diskursen för varje samtalssekvens som presenteras. I den här studien befinner sig interaktionen växelvis i en komisk och i en idrottslig diskurs. Den idrottsliga kan ses som överordnad den komiska.

Därutöver beskrivs också två andra underordnade diskurser som jag inkluderar i analysen när de aktualiseras: en kollegial och en medial diskurs. Dessa visar på relationer som etableras samtalsdeltagarna och publiken emellan. I den kollegiala diskursen har samtalsdeltagarna främst ett kollegialt tilltal i samtalet, vilket exempelvis framgår genom att de som samtalar i studion visar att de 
känner till vad som händer sinsemellan också utanför studiosamtalen. I den mediala diskursen synliggörs tv-publikens eventuella förhoppningar om hur det ska gå i tävlingarna, vilket skapar tittarperspektiv i samtalet. Den växelverkan som finns mellan den mediala och den kollegiala diskursen kan sägas indikera om de som interagerar i studion främst tilltalar tv-tittarna eller varandra. De båda diskurserna visar också på att samtalen kan ses både som arbetsrelaterade samtal med fokus på en uppgift (Holmes 2000 s. 37), och som underhållning skapad för en tv-publik (Mullany 2002 s. 7).

Den idrottsliga diskursen är ständigt aktuell eftersom det är idrott som är det övergripande temat, specifikt längdskidor. De andra diskurserna blir framträdande genom vad samtalsdeltagarna i studion pratar om. Även om en samtalsdeltagare exempelvis aktualiserar en komisk diskurs betyder det inte att de andra behöver acceptera den. Det kan visa sig genom att en person säger något skämtsamt och en annan besvarar yttrandet med allvar, det vill säga utan att erkänna det förra uttalandet som skämtsamt.

\subsection{Samtalsanalys i vid bemärkelse}

Transkriptionerna i artikeln är presenterade utifrån en samtalsanalytisk konvention för att lyfta fram de aspekter av samtalen som är relevanta för analysen (Hutchby \& Wooffitt 2008 s. 83). Transkriberingsprincipen som används är skriftspråksnormerad, snarare än uttalsnära, med undantag för ljudhärmande ord och korta ord som står ensamma (exempelvis $n \ddot{a}$, näj). Samtalsanalys används här i vid bemärkelse, vilket innebär att hänsyn tas även till kön som inom FDPA ses som viktigt. Även analys av vissa multimodala inslag ingår när det är möjligt, det vill säga när bildproduktionen medger det. Det som förekommer i analysen är gester, blickar, ansiktsuttryck och huvudrörelser. Dessa multimodala inslag tolkas kontextuellt när de kan ses som kommunikativa. Enligt Isabella Poggi (2007 s. 109) kan gester tolkas som kommunikativa då de har som mål att ge andra information. Att klia sig i håret skulle exempelvis inte ses som en kommunikativ gest. Gesten att hålla ut handen kan däremot ses som ett erbjudande om att ta turen (Martinec 2001 s. 133). Olika huvudrörelser kan fungera som respons i samtal; nickningar kan exempelvis användas som stödsignaler (Poggi 2007 s. 288). Blickar kan ha en samtalsreglerande funktion (ibid.).

I analysen av studiosamtalen är responsen central, eftersom den är med och avgör om skämtet kan anses framgångsrikt eller inte (jfr Söderlund 2016 s. 60- 


\section{Hanna Söderlund}

61). Misslyckat skämtande har i den här analysen inget att göra med kvaliteten på skämtet, utan bygger på vilken respons skämtandet får. I en komisk diskurs är den prefererade responsen normalt sett skratt eller att mottagarna på ett eller annat sätt erkänner den överlappande komiska diskursen och därmed skämtandet. Skratt (hehe) är den respons som jag menar utgör tillräcklig respons vilket också leder till att ett skämt kan bli framgångsrikt. Även att fortsätta någon annans skämtande ses i den här analysen som tillräcklig respons, såvida den också följs av skratt. Otillräcklig respons i den komiska diskursen kan utgöras av frånvaro av respons, det vill säga när en paus uppstår. Men även minimal respons $(\mathrm{mm}, \mathrm{mhm})$ uppfattar jag som otillräcklig i den komiska diskursen eftersom den inte ger skämtandet någon bekräftelse. Snarare kan den minimala responsen ses som respons i en idrottslig diskurs, som alltså relaterar till innehållet i uttalandet snarare än till skämtandet. Leenden tolkar jag som ett sätt att visa välvilja eller som minimal respons, men inte nödvändigtvis som tillräcklig respons i en komisk diskurs. För urvalet som gjorts till den här artikeln ligger inte fokus på att undersöka respons, även om den också diskuteras i analysen när så är relevant.

\subsection{Maktpositioner kopplade till social närhet eller distans}

I analysen av samtalen undersöks hur makt förhandlas fram och om samtalsdeltagarna uppnår starka maktpositioner eller om de avvisas från dessa i de olika diskurserna. Parallellt med att maktpositioner förhandlas fram uppstår även social närhet eller distans. Även om en maktposition försvagas i den komiska diskursen behöver det inte nödvändigtvis innebära att det uppstår social distans samtalsdeltagarna emellan. Nedan resonerar jag därför om hur starka maktpositioner uppnås och hur social närhet uppstår.

Responsen bidrar till hur makt förhandlas fram i samtalen, om starka maktpositioner kan uppnås eller inte. En samtalsdeltagare som får tillräcklig respons i den komiska diskursen kan uppnå en stark maktposition och därmed framstå som humoristisk. Otillräcklig respons leder i stället till att den som skämtar inte kan framstå som humoristisk och därmed inte heller uppnå en stark maktposition. Tillräcklig respons bidrar också till social närhet, medan det inte uppstår någon social närhet om responsen uteblir eller är otillräcklig (Trouvain \& Truong 2017 s. 342).

Att bli måltavla för ett skämt kan innebära att få en svag maktposition i den komiska diskusen i och med att man görs låg sett till makt. Samtidigt kan skäm- 
tandet leda till att social närhet uppstår, eftersom det också är ett sätt att upprätthålla gruppsolidaritet (Hay 2000 s. 717). Dessutom använder människor oftare humor som gör personer till måltavla om de uppfattar att de har samma status (Purdie 1993 s. 65), eller är socialt nära eftersom det är förknippat med mindre risk för ansiktshot. I en komisk diskurs kan social närhet därmed uppstå också i och med potentiellt ansiktshotande uttalanden, eftersom dessa är möjliga mellan personer som är socialt nära (Brown \& Levinson 1987 s. 72). Respektstrategier som används i en komisk diskurs kan innebära att man låter bli att göra andra till måltavla för skämtande, eller att meningsskiljaktigheter som annars skulle kunna uppfattas som potentiellt ansiktshotande snabbt leder till konsensus. Dessa strategier kan därför kopplas samman med social distans.

I den idrottsliga diskursen uppnås en stark maktposition genom att man framstår som kompetent. Kompetens förhandlas fram genom innehållet i det som sägs, genom att en person framstår som att den är kunnig eller hårt arbetande. I den mediala diskursen kan den som har tittarnas förhoppningar och förväntningar i åtanke uppnå en stark maktposition. I den kollegiala diskursen analyseras inte maktpositioner specifikt. Däremot diskuteras social närhet och distans också i samband med dessa tre senast nämnda diskurser. Solidaritetsstrategier i samtalen kan bidra till social närhet. Social distans uppstår om istället respektstrategier används.

I studien ingår inte att analysera programledarens maktpositioner. Hans institutionella maktposition skiljer sig från övriga närvarande personers i kraft av att han leder samtalen och därmed både fördelar turen och initierar de flesta skämten. I och med detta är han starkt bidragande till andras möjligheter i samtalet, när det gäller både om maktpositioner kan uppnås och om social närhet eller distans uppstår.

\section{Analys}

Nedan presenteras fem exempel från materialet där samtalsdeltagarna interagerar i en komisk diskurs. I analysen diskuteras hur maktpositioner förhandlas fram samt hur social närhet och distans uppstår under förhandlingarna av maktpositioner. Inledningsvis presenteras exempel där social närhet uppstår, och därefter exempel där det i stället uppstår viss social distans.

Sekvenserna som presenteras har valts ut eftersom de illustrerar generella mönster i materialet. En tendens är att när kommentatorerna deltar i samtalet 
via infälld bild uppstår skämtande som bidrar till både att de kan uppnå starka maktpositioner och att social närhet uppstår. Med den manliga experten är tendensen att social närhet uppstår, men i stället genom ett mer utmanande skämtande där han blir måltavla för skämtande eller genom verbala dueller. Social distans uppstår med den kvinnliga experten genom att skämtandet innehåller respektstrategier. I beskrivningarna till transkriptionerna anges vilket av studiosamtalen som avses genom att de är numrerade 1-7 utifrån den siffra studiosamtalet givits i materialförteckningen.

\subsection{Kollegialitet skapar social närhet}

I den kollegiala diskursen sker skämtande som gör att social närhet uppstår, samtidigt som alla i interaktionen uppnår starka maktpositioner. I exempel (1) uppstår social närhet när skidkommentatorerna släpps in i samtalen via infälld bild. Programledaren påvisar att kommentatorerna Anders och Jacob ska kommentera två stora lopp i SVT:s sändningar dagen därpå: herrarnas femmil i VM och Vasaloppet dessförinnan. Maktpositioner i den här sekvensen diskuteras främst utifrån den idrottsliga och den komiska diskursen.

\section{(1) Studiosamtal 6, 00:34:00-00:34:49}

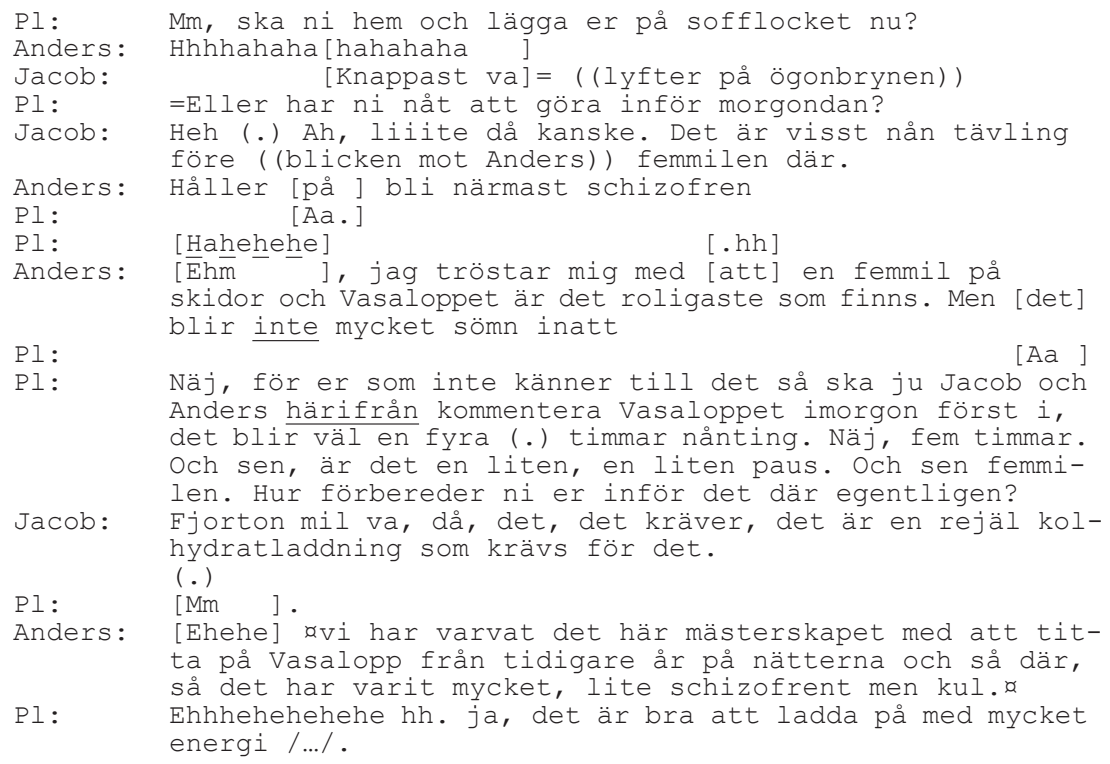


Programledarens inledande fråga sker i en medial diskurs, genom att han skämtsamt låtsas som om han inte vet vad kommentatorerna Jacob och Anders ska göra: ska ni hem och lägga er på sofflocket nu ( $\operatorname{rad} 1)$. Den komiska diskursen aktualiseras här i och med att det programledaren säger inte är sant, vilket kommentatorerna också förstår. När Anders skrattar i samband med programledarens fråga ( $\operatorname{rad} 2)$, interagerar också han i den komiska diskursen genom att visa att han tolkar yttrandet skämtsamt. Jacob besvarar i stället programledarens fråga på ett sätt som kan visa både på allvar och på komik, genom att påvisa att programledaren har fel: knappast va $(\operatorname{rad} 3)$. Det indikerar att han väljer att interagera i en medial diskurs, alltså med tv-publiken som främsta mottagare. Efter programledarens följdfråga: eller har ni nåt att göra inför morgondan? ( $\mathrm{rad} 4)$ interagerar Jacob i en komisk diskurs genom sitt svar: liiite då kanske. Det är visst nån tävling före femmilen där ( $\operatorname{rad} 5-6)$. Interaktionen fortsätter därefter överlappande i en komisk och en kollegial diskurs när arbetet omtalas i skämtsamma ordalag kollegor emellan. Anders beskriver sin uppfattning inför det arbete som har gjorts och som ska göras: håller på bli närmast schizofren ( $\mathrm{rad} 7)$ och vi har varvat det här mästerskapet med att titta på Vasalopp från tidigare år på nätterna $(\operatorname{rad} 23-24) .{ }^{3}$ Programledaren ger respons genom att han skrattar med eftertryck ( $\operatorname{rad} 9$ och 26). Även Jacob fortsätter i en komisk diskurs när han säger: fjorton mil va, då, det kräver, det är en rejäl kolhydratladdning som krävs för det ( $\operatorname{rad} 19-20)$. Programledaren ger Jacob minimal respons och Anders ger tillräcklig respons genom att han skrattar, även om det sker efter en kort paus (rad 22 och 23). Programledaren synliggör kontrasten mellan den kollegiala och den mediala diskursen när han förklarar för tv-publiken: för er som inte känner till det så ska ju Jacob och Anders härifrån kommentera Vasaloppet imorgon först $(\operatorname{rad} 14-18)$.

Interaktionen i exempel (1) mellan programledaren och de manliga kommentatorerna sker växelvis i en kollegial och en medial diskurs. Den mediala diskursen synliggörs genom att programledaren låtsas som om han inte vet att kommentatorerna har mycket jobb framöver samt att han senare i sekvensen berättar för tv-publiken hur det ligger till. I samband med den kollegiala diskursen aktualiseras också den komiska. Skämtandet blir därmed kollegialt och kan uppfattas som internt. Som tv-tittare kan man förstå skämtandet direkt om man vet hur tv-tablån ser ut. I annat fall låts man som tv-publik under samtalet gång förstå att de ägnar sig åt just skämtande i studion.

\footnotetext{
${ }^{3}$ Skämtandet sker här på bekostnad av en socialt icke-hegemonisk grupp: personer med schizofreni. Det ingår dock inte i mitt syfte att undersöka icke-närvarande personer/grupper, varför jag inte kommenterar skämtet ur den aspekten närmare.
} 
I interaktionen blir kommentatorernas skämtande genomgående framgångsrikt eftersom de får tillräcklig respons. Det gör att de kan framstå som humoristiska i den komiska diskursen. Av exempel (1) framgår också att kommentatorerna arbetar hårt (på nätterna) och att de i det närmaste är oersättliga eftersom de ska kommentera två stora lopp på raken som går av stapeln på två olika platser. Därmed kan de även framstå som kompetenta i den övergripande idrottsliga diskursen.

De manliga kommentatorerna kan därför genomgående uppnå starka maktpositioner i exemplet, vilket programledaren bidrar till genom samtalsstöd och sättet han skämtar på. I materialet finns fler liknande exempel vilket gör samtalsmönstret till en tendens. Eftersom båda kommentatorerna är män, kopplas de starka positioner de uppnår oundvikligen också ihop med manliga samtalsdeltagare. Kotthoff menar att den starka maktpositionen oftare är tillgänglig för män, inte minst genom andras samtalsstöd (1997 s. 140). I programmet finns inte någon kvinnlig kommentator, vilket innebär att det inte går att koppla samman kommentatorspositionen med kvinnliga samtalsdeltagare. Den här fallstudien bygger på ett urval där samma personer är kommentatorer. Men dessa två personer har också varit dominerande som kommentatorer inom skidsporten under mer än två decennier (Hilmersson 2017), vilket gör att urvalet är representativt för hur det ofta ser ut när skidsport kommenteras i SVT. Den manliga dominansen i kommentatorsbåset kan i förlängningen därför säga något om möjligheten att vara kvinnlig kommentator, eftersom representationer också är avgörande för konstruktionen av kön (Markula 2009 s. 6).

Skämtandet som sker i den kollegiala diskursen i det här exemplet indikerar att det uppstår social närhet programledaren och de manliga kommentatorerna emellan, på grund av hur de skämtar och den genomgående tillräckliga responsen.

\subsection{Ansiktshotande humor bidrar till social närhet}

I studion används en komisk diskurs i sammanhang som skulle kunna vara ansiktshotande: vid skämtande som gör någon till måltavla och vid meningsskiljaktigheter. Utmanande skämtande kan visa på social närhet eftersom det inte behöver bli ansiktshotande mellan personer som är socialt nära (Brown \& Levinson 1987 s. 72).

Programledaren gör återkommande den manliga experten Mathias till före- 
mål för skämtande. Det finns även ett tillfälle då den kvinnliga experten Johanna blir föremål för skämtande efter att programledaren inlett med att skämta om Mathias. I exempel (2) nedan är det dock Mathias som blir måltavla för skämtande. Programledaren introducerar ett inslag där experten Mathias har följt med skidåkaren Marcus Hellner ut i skidspåren.

\section{(2) Studiosamtal 2, 00:14:16-00:14:26}

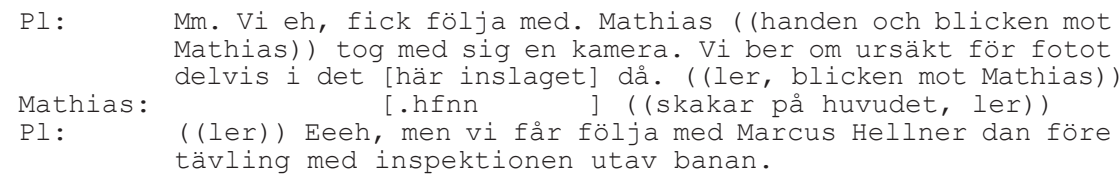

Programledaren inleder med att kommentera det kommande inslaget om Marcus Hellner i skidspåren genom att säga: Mathias tog med sig en kamera. Vi ber om ursäkt för fotot delvis $i$ det här inslaget då ( $\operatorname{rad} 1-3)$. I omgångar vänder han blicken och pekar med hela handen mot Mathias, samtidigt som han ler. Han visar tydligt med blick, gest och ord att han syftar på Mathias. Leenden och ton indikerar också att han kommenterar experten Mathias dåliga fotokunskaper genom att använda en komisk diskurs. Mathias respons är att han skrattar till och skakar på huvudet (rad 4). Det är Mathias som blir föremål för skämtandet och han kan sägas acceptera det genom att han också skrattar. Han skakar visserligen på huvudet, men ler och säger inte emot.

Att bli föremål för skämtande kan innebära att få en svag maktposition (Purdie 1993 s. 65). Men genom skämtandet uppstår samtidigt en humoristisk stämning mellan den manliga experten och programledaren. I det här materialet är det, som berörts ovan, återkommande för den manliga experten att bli föremål för skämtande, medan detta inte i samma utsträckning gäller för den kvinnliga experten. Även i andra tv-sammanhang kan man se att en låg men humoristisk position innehas av en man i och med en manlig programledares skämtande, exempelvis i det brittiska frågeprogrammet $Q I$ (Mills 2011 s. 144).

En annan typ av interaktion som uppstår i den komiska diskursen är meningsskiljaktigheter samtalsdeltagarna emellan, det vill säga när olika åsikter går emot varandra. Att uttrycka dessa i en komisk diskurs kan vara en strategi för att dämpa det potentiellt ansiktshotande i situationen. Mellan programledaren och den manliga experten leder meningsskiljaktigheterna till en verbal duell. Att en verbal duell alls är möjlig utan att bli ansiktshotande, kan visa på att det finns social närhet dem emellan. I exempel (3) uppstår meningsskiljaktigheter när man i studiosamtalen diskuterar Marit Björgen (Norge) 
och hennes många medaljer i VM- och OS-sammanhang. Mathias säger att han är otroligt imponerad, varpå han jämför Björgens prestation och träningsinsats med att spela pingis. ${ }^{4}$ Programledaren menar att alla pingisälskare nu kommer att bli arga.

\section{(3) Studiosamtal 3, 00:48:22-00:48:42}

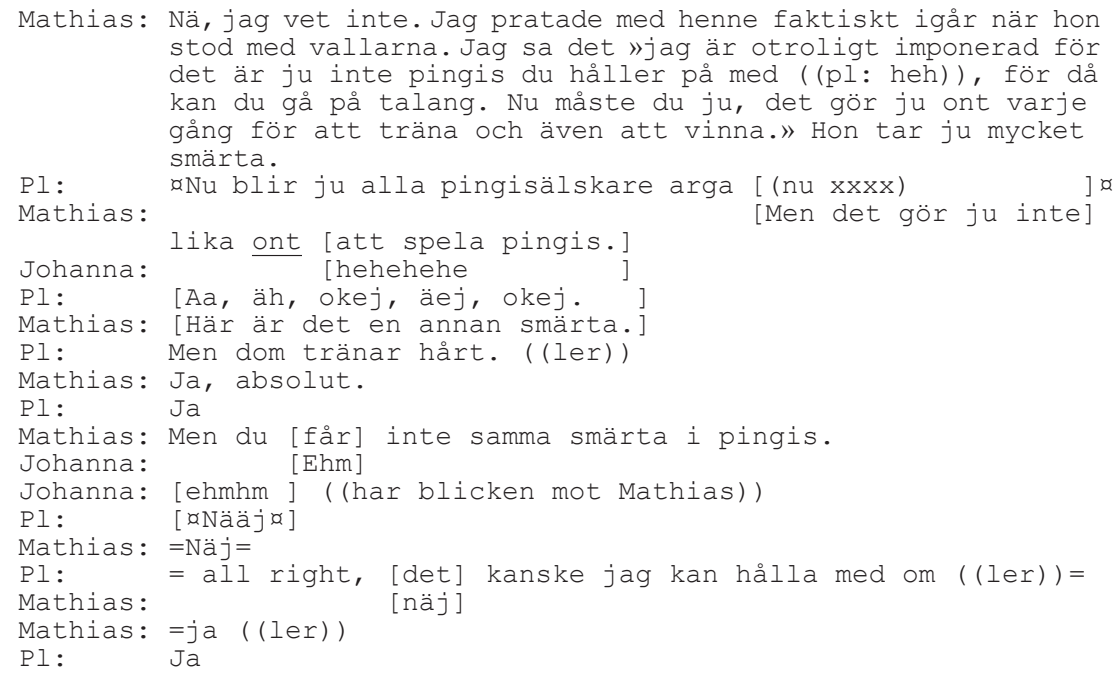

Experten Mathias inleder samtalet med att referera till ett samtal han haft dagen innan. I exempel 3 citerar han det han sagt till Marit Björgen: jag är otroligt imponerad för det är ju inte pingis du håller på med $(\operatorname{rad} 2-3)$. Under Mathias tal hörs (vad jag uppfattar som) programledaren skratta till. Programledaren motsätter sig direkt Mathias uttalande genom att med leende röst säga: nu blir ju alla pingisälskare arga ( $\mathrm{rad} 7)$ när Mathias implicerar att pingis är lätt och att skidor är tungt. Programledarens yttrande kan vara en ansiktsräddande reparation å Mathias vägnar för att han är på väg att trampa tv-tittande pingisälskare på tårna. Det innebär att turen sker i en medial diskurs när programledaren har tittarnas eventuella intressen i andra sporter i åtanke. Johanna skrattar, vilket innebär att skämtandet som uppstår får tillräcklig respons (rad 10). Programledarens leende röst och Johannas skratt gör också att en komisk diskurs introduceras ( $\mathrm{rad} 7,10)$. Mathias förklarar sig med att

${ }^{4}$ I idrottssammanhang talar man vanligtvis om bordtennis, men i studiosamtalet refererar de genomgående till sporten som pingis, varför även jag gör det. 
säga: men det gör ju inte lika ont att spela pingis. Här är det en annan smärta (rad 8-9 och 12). Programledaren tar turen samtidigt och visar att han förstår och eventuellt accepterar detta: ah, äh, okej, äej, okej (rad 11). Därefter fortsätter programledaren med att leende säga att de som spelar pingis ändå tränar hårt (rad 13). Det enas han med Mathias om. Däremot vidhåller Mathias att det inte är samma smärta i pingis ( rad 16). Johanna skrattar åt detta vänd mot Mathias (rad 18). Avslutningsvis tycks programledaren lite motvilligt gå med på Mathias inställning: all right det kanske jag kan hålla med om samtidigt som han ler ( $\operatorname{rad} 21)$. Mathias bekräftar genom att säga: näj och ja (rad 22-23).

I samband med att programledaren ställer sig på »pingisälskarnas» sida avvisar han Mathias från en stark maktposition i den mediala diskursen. I Mathias jämförelse av idrotter har han inte tv-tittarnas eventuella andra idrottsintressen $\mathrm{i}$ åtanke, utan främst de skidintresserades. Den komiska diskurs som introduceras bidrar till att dämpa det eventuella ansiktshot som annars skulle kunna uppstå i och med meningsskiljaktigheterna mellan programledaren och den manliga experten. Eftersom alla i interaktionen skrattar eller ler genom nästan hela sekvensen interagerar samtliga i en komisk diskurs. Mathias kan samtidigt framstå som humoristisk när såväl programledaren som Johanna skrattar vända mot honom. Meningsskiljaktigheterna fortgår dock genom hela interaktionen i en idrottslig diskurs vilket gör att ansiktshotet utvecklas till en verbal duell där konsensus uppnås först i slutet och till synes motvilligt. I materialet är det återkommande att motsättningar mellan programledaren och den manliga experten blir uppenbara, i stället för att de snabbt uppnår konsensus. Verbala dueller och aggressiva skämt är i olika offentliga sammanhang som undersökts förekommande män emellan. Ett utmanande beteende är kanske mer möjligt och till och med förväntat för män, enligt studier av dokumentärer på tv (Chovanec $2017 \mathrm{~s}$. 46), men också i skolmiljö bland elever på fordonsprogrammet (Kärnebro 2013 s. 298).

Utmanande skämtande kan vara ansiktshotande, men behöver inte bli det mellan personer som står varandra socialt nära. Reellt ansiktshotande kommentarer i genren tv-underhållning är sannolikt också ovanliga. Att de alls kan yttras kan därför indikera att det finns en social närhet mellan personerna som skämtar på det sättet, i det här fallet programledaren och den manliga experten. 


\subsection{Meningsskiljaktigheter skapar viss social distans}

Meningsskiljaktigheter uppstår också mellan programledaren och den kvinnliga experten. Dessa avrundas dock snabbt och man kan gå vidare i samtalen. Den komiska diskurs som introduceras bidrar också i dessa fall till att minska det potentiella ansiktshotet. Det faktum att samtalsdeltagarna snabbt kommer till konsensus kan ses som respektstrategier som indikerar viss social distans. Nedan presenteras två exempel där meningsskiljaktigheter uppstår, där först programledaren och sedan den kvinnliga experten är den som introducerar den motstridiga åsikten.

I exempel (4) har de diskuterat norska skidåkaren Marit Björgens karriär och hur hon har för avsikt att fortsätta åtminstone en säsong till. Björgen har varit överlägsen i skidåkningen under många år, och Johanna menar att hon inte ser fram emot att Björgen ska avsluta sin karriär, vilket programledaren har en motsatt uppfattning om.

\section{(4) Studiosamtal 6, 00:43:48-00:44:01}

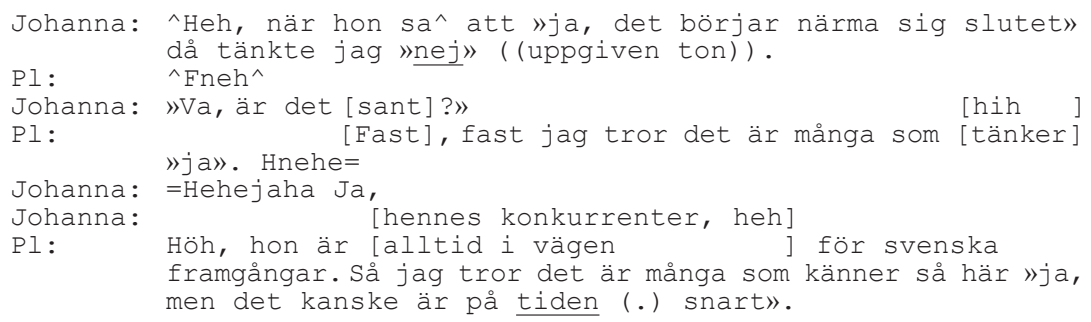

Experten Johanna beskriver sin uppfattning om att Marit Björgen ska avsluta sin karriär när hon säger: då tänkte jag »nej, va, är det sant» ( $\operatorname{rad} 1-2$ och 4). Genom intonation och sin anekdotiskt beskrivna reaktion interagerar Johanna i en komisk diskurs. Programledaren skrattar under tiden till ( $\mathrm{rad} 3)$, vilket gör att interaktionen fortsätter i en komisk diskurs. Responsen gör också Johannas skämtande framgångsrikt. Skrattet kan också tolkas som ett sätt att linda in den meningsskiljaktighet som därefter uppstår då programledaren uttrycker den motsatta åsikten genom att introducera den som »mångas»: fast, fast jag tror det är många som tänker »ja» (rad 5-6). Interaktionen menar jag sker i en medial diskurs, där programledaren förhåller sig till tv-publikens (som jag har uppfattat det) förhoppningar och förväntningar om att få se framgångar för svenska skidåkare snarare än norska. Den komiska diskursen, som introduceras med skratt, kan ha en dämpande effekt på vad som annars skulle kunna bli ansiktshotande meningsskiljaktigheter. Johanna skrattar samtidigt som hon beskriver vilka hon menar att 
programledaren syftar på: ja, hennes konkurrenter ( $\operatorname{rad} 7-8)$. Programledaren utvecklar sin ståndpunkt något avslutningsvis när han menar: hon är alltid $i$ vägen för svenska framgångar. Så jag tror det är många som känner så här »ja, men det kanske är på tiden snart» ( $\operatorname{rad} 9-11)$. Talet sker delvis samtidigt som Johannas. Även om det finns allvar i uttalandet tolkar jag det som att det krävs en komisk diskurs för att kunna uttrycka en förhoppning om att en så framgångsrik skidåkare som Marit Björgen ska avsluta sin karriär.

I exempel (5) är det Johanna som inleder meningsskiljaktigheterna med programledaren. I studion diskuterar de hur tittarna kan vara med och tävla i något som kallas »Vinterexperten». Tävlingen innebär att SVT:s sportredaktion lägger ut frågor på sin webbplats och i sin mobil-applikation gällande olika skidtävlingar för dagen. Experterna i studion har ett eget lag där de är med och tävlar mot tv-tittarna, vilket programledaren syftar på när han säger att Johanna har gjort ett val i en fråga. Johanna ifrågasätter dock om det verkligen bara var hennes val.

\section{(5) Studiosamtal 1, 00:11:16-00:11:34}

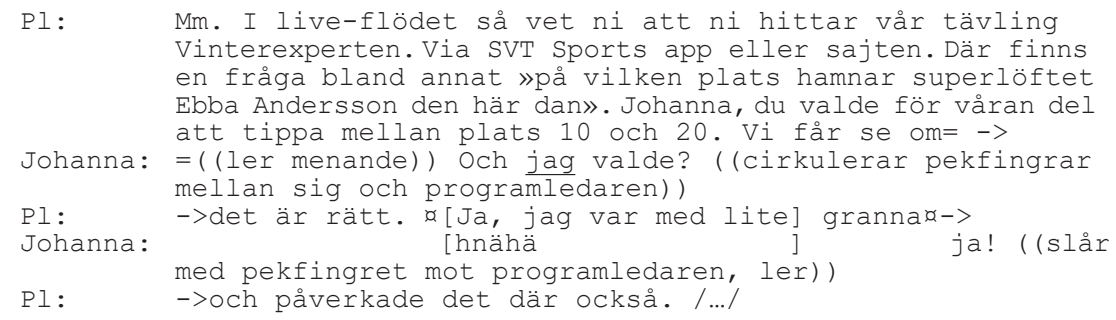

Efter programledarens inledande kommentar att tittarna nu kan gå in och besvara frågor i Vinterexperten säger han: Johanna, du valde för våran del att tippa mellan plats 10 och 20. Vi får se om det är rätt ( $\operatorname{rad} 4-5$ och 8). Experten Johanna ler menande och ifrågasätter direkt, utan paus, uttalandet när hon frågande säger: och jag valde, med betoning på jag. Samtidigt cirkulerar hon pekfingrarna mellan sig och programledaren för att kommunicera att han nog också var med och gjorde valet (rad 6-7). Den komiska diskursen introduceras här genom leenden, Johannas ton samt hennes gest med fingrarna som visar att båda var med och gjorde valet. Även här kan den komiska diskursen vara ett sätt att dämpa den potentiellt ansiktshotande meningsskiljaktigheten. Programledaren tycks acceptera att han haft ett finger med i spelet $\mathrm{i}$ och med responsen: ja, jag var med lite granna och påverkade det där också, vilket sägs med leende röst ( $\mathrm{rad} 8$ och 11). Den leende rösten kan vara ett sätt att visa att han också fortsätter sin interaktion i en komisk diskurs. Johanna skrattar och säger $j a$, med emfas, samtidigt som hon slår med pekfingret mot 


\section{Hanna Söderlund}

programledaren som för att poängtera att hon har rätt ( $\operatorname{rad} 9-10)$. Även om programledaren antyder att han förstår hennes skämtande intention, orienterar han sig i sitt svar ändå främst mot den idrottsliga diskursen i och med att han utan omsvep erkänner att hon har rätt. Han går därefter direkt vidare till ett nytt samtalsämne. Johannas skämtande får inte tillräcklig respons eftersom ingen annan än hon själv skrattar. Hennes skämtsamma inlägg blir därför inte entydigt framgångsrikt.

I sekvenserna där meningsskiljaktigheter uppstår, sker förhandlingen av maktposition i olika diskurser. När den kvinnliga experten inte tar hänsyn till tv-publikens förhoppningar om svenska framgångar blir hon avvisad från en stark maktposition av programledaren i en medial diskurs (exempel 4). I den idrottsliga diskursen kan hon dock framgångsrikt uppnå en stark maktposition genom att framstå som kompetent när hon påvisar att hon och programledaren haft gemensamt ansvar för valet i tävlingen Vinterexperten (exempel 5). Skulle valet senare visa sig vara fel så är det inte bara hon som ska behöva stå för resultatet i tävlingen. Den kvinnliga experten kan samtidigt sägas utmana programledaren genom att påvisa att han försökt ge henne ensamt ansvar. Att använda humor för att på olika sätt ta kontrollen i samtal är en strategi som effektivt kan användas för att uppnå starka maktpositioner, kanske särskilt när de tycks svåra att uppnå.

I den komiska diskursen kan den kvinnliga experten uppnå en stark maktposition då programledaren skrattar åt hennes skämtande i exempel (4), men inte entydigt i exempel (5) då hon inte får tillräcklig respons, även om programledaren använder en leende röst. En återkommande tendens i materialet, som inte utforskas vidare här, är att den kvinnliga experten inte alltid får tillräcklig respons i den komiska diskursen. Uteblivet skratt från de andra i studion gör att hon har svårt att framstå som humoristisk.

Meningsskiljaktigheterna leder i båda fallen snabbt till konsensus mellan programledaren och den kvinnliga experten. Att konsensus snabbt uppnås kan ses som respektstrategier (Norrby 2014 s. 224). Respektstrategierna i kombination med att den kvinnliga experten inte genomgående kan framstå som humoristisk eftersom det inte alltid är någon som skrattar när hon skämtar, bidrar till att det uppstår viss social distans mellan henne och programledaren.

\section{Sammanfattande diskussion}

Syftet med studien har varit att undersöka hur kön (re)produceras genom de möjligheter skidexperter och skidkommentatorer på tv har att uppnå starka maktpositioner när de använder humor. Jag har visat exempel på hur makt för- 
handlas fram genom humor i SVT:s sändningar från VM i längdskidor. Fokus har varit att undersöka hur samtalsdeltagarna interagerar i en komisk diskurs och vilken respons de får. Dessutom har jag diskuterat om social närhet eller distans uppnås i samtalen.

Både meningsskiljaktigheter och humor där någon blir föremål för skämtande kan sägas blottlägga vissa maktrelationer i den komiska diskursen. Det är främst med den manliga experten som programledaren skämtar på ett socialt utmanande sätt. Att bli föremål för skämtande innebär att få en maktposition försvagad. Samtidigt kan den typen av skämtande och även verbala dueller som uppstår i samtal tolkas som solidaritetsstrategier (Hay 2000 s. 717). Med den kvinnliga experten skämtas det inte i samma utsträckning på ett utmanande sätt. I stället leder interaktionen snabbt till konsensus. Sociala maktförhållanden mellan personer är något som hanteras i varje given situation i det ansiktsrelaterade arbetet, enligt Brown och Levinson (1987 s. 74). Skulle det uppstå ett större ansiktshot om den manliga programledaren skämtade utmanande med den kvinnliga experten? Lampert m.fl. belyser att män i vängrupper tenderar att undvika att skämtsamt reta sina kvinnliga vänner eftersom det kan uppfattas som aggressivt (2006 s. 66). Kan det även gälla i studiosamtal, kollegor emellan?

Den kollegiala diskursen aktualiseras främst mellan programledaren och de manliga kommentatorerna. Skämtandet sker då växelvis i den kollegiala och den mediala diskursen vilket visar på olika tilltal: samtal kollegor emellan och med tv-publiken som mottagare. I de fall då kollegorna främst vänder sig till varandra kan skämtandet uppfattas som internt. Tv-publiken låts först i ett senare skede förstå bakgrunden till skämtandet. Innehållet i skämtandet i kombination med att kommentatorerna uppnår starka maktpositioner bidrar till att det uppstår en humoristisk stämning och samtidigt social närhet. Kommentatorerna kan genomgående framstå som både kompetenta och humoristiska.

I den mediala diskursen blir både den manliga och den kvinnliga experten avvisade. Den manliga experten avvisas när han uppfattas som partisk till skidsport i och med att han nedvärderar insatsen som krävs för att träna pingis. Den kvinnliga experten avvisas då hon visar lojalitet till norska framgångar, $\mathrm{i}$ stället för att visa respekt för tv-publikens eventuella förhoppningar om svenska framgångar. Idrottsliga diskurser har ofta nationalistiska förtecken där framgångar för den egna nationen är det som premieras (Tolvhed 2008 s. 88). Denna inställning är något den kvinnliga experten bryter mot $\mathrm{i}$ och med sitt uttalande. Det kan kanske ses som sekundärt för skidexperterna att framstå som opartiska till olika sporter eller att ha tv-tittarnas förhoppningar i åtanke, givet att de är experter på just skidor med fokus på goda skidprestationer oavsett vem 
som står för dem. Däremot kan det sägas ingå i programledarens institutionella roll som företrädare för SVT att ha tv-tittarna och idrottsneutralitet i åtanke. Hans roll i den idrottsliga diskursen kan därmed uppfattas som att han till viss del tyglar experterna om de gör avsteg från dessa värden. Möjligen är det en orsak till att experterna blir avvisade.

Endast den kvinnliga experten får respons som gör att hon inte entydigt kan uppnå en stark maktposition när hon interagerar i en komisk diskurs. Även om det inte går att säga vad den otillräckliga responsen beror på, bidrar den till att den humoristiska stämningen samtalsdeltagarna emellan uteblir. Uteblivet skratt vid skämtande kan ses som att den andra delen i ett närhetspar saknas (Norrick 1993 s. 23). Jag menar också att den obekväma stämning som kan uppstå på grund av uteblivet skratt antagligen inte fyller ett önskat syfte i ett tvprogram som i hög grad går ut på att underhålla. Det finns i andra sammanhang exempel på att kvinnor tycks ha det svårare att framstå som humoristiska på grund av hur de behandlas av programledare eller andra samtalsdeltagare. I brittiska $Q I$ tycks de kvinnliga deltagarna missgynnas av programledaren, på grund av sin skämtteknik (Mills 2011 s. 140). I Parlamentet missgynnas kvinnliga komiker både av andra komiker och av programledaren eftersom de oftare än männen blir avvisade när de skämtar (Söderlund 2016 s. 171). Möjligheten finns att övergripande, sociokulturella maktstrukturer i den komiska diskursen här visar sig på ett lokalt plan.

I den idrottsliga diskursen kan den kvinnliga experten i studion dock uppnå en stark maktposition genom att använda humor. Hon gör det genom ett utmana programledaren då han försökt ge henne ensamt ansvar i en fråga. Exemplet visar på att humor kan skapa möjligheter att ta kontroll i samtal, och på så vis försöka förhandla sig till bättre maktpositioner. Strategin att använda humor för att ta kontroll i samtal använder också kvinnliga doktorander i seminariesammanhang (Gunnarsson 2002 s. 259) och kvinnliga komiker i humorprogram på tv (Söderlund 2016 s. 184).

Det är främst de manliga samtalsdeltagarna emellan som det uppstår en humoristisk stämning, vilket också bidrar till att det uppstår social närhet. Med den kvinnliga expertens uppstår i viss utsträckning istället social distans i och med olika respektstrategier och att den humoristiska stämningen ibland uteblir. Om det är en asymmetri som återkommer kan den bidra till upplevelsen av att vissa har en gemenskap som alla inte är en del av, både för tv-tittarna och för dem som deltar i samtalen. 


\section{Slutsatser}

Alla deltagare studiosamtalen har möjlighet att skapa sina egna förutsättningar eller stödja andras möjligheter att uppnå starka maktpositioner, även om programledaren förstås har en institutionell maktposition som är speciell. Samtidigt kan de tendenser som framträder i studiosamtalen synliggöra vissa maktrelationer, lokalt och strukturellt.

Även om det är en fråga om få individer i studien är såväl makt som kön något som i all interaktion är under ständig omförhandling, om än inom en snäv och normativ struktur (Butler 2007 s. 88). Hur de kvinnliga och manliga experterna och kommentatorerna behandlas i den komiska diskursen i dessa samtal behöver inte nödvändigtvis bero på att individerna är kvinnor och män. Däremot bidrar interaktionen i studion till att (re)producera föreställningar som finns om vilka positioner kvinnliga och manliga experter och kommentatorer kan ha i en komisk och i en idrottslig diskurs, vem som kan framstå som humoristisk och vem som kan framstå som kompetent. Den roll medierna har för vår förståelse av världen gäller inte minst de föreställningar som finns om kön. Maria Edström menar exempelvis att i medierna »sätts gränser för kön hela tiden vare sig vi märker det eller inte» (2001 s. 93). Framställningen av kvinnliga och manliga experter och kommentatorer i just dessa samtal når en miljonpublik. De blir därför en del av de hegemoniska föreställningar som finns om kön, makt och humor i idrott, också på ett generellt plan.

\section{Transkriptionsnyckel}

\begin{tabular}{|c|c|c|}
\hline$()$. & & kort paus (mindre än en sekund) \\
\hline jaaa & & förlängning av ljud \\
\hline jaså? & & frågeintonation \\
\hline arsågod & & sägs med emfas \\
\hline ^jaha^ & & sägs skrattande \\
\hline aintex & & sägs med leende i rösten \\
\hline he & & intensivt skratt med betoning \\
\hline à» & & citerar sig själv eller andra \\
\hline hh & & hörbar inandning \\
\hline ॰ huhu。 & & låg röstvolym \\
\hline $\begin{array}{l}\text { B: sådär } \\
\text { K: }\end{array}$ & $\begin{array}{l}\text { [tack] } \\
\text { [tack] }\end{array}$ & samtidigt tal \\
\hline & & repliken fortsätter på ny rad (som anges med ->) \\
\hline & & repliken följer omedelbart på den föregående (latchning) \\
\hline (er)) & & beskrivning av aktivitet, kroppsliga modaliteter \\
\hline$x \mathrm{x})$ & & ohörbart (ett eller flera ord) \\
\hline
\end{tabular}




\section{Materialförteckning}

Studiens urval av tv-sända studiosamtal från VM i längdskidor, Lahtis 2017:

\section{nr \\ 1 \\ 2 \\ 3 \\ 4 \\ 5 \\ 6 \\ 7}

Studiosamtal Sändningstid
Längd analyserat material

25 februari ca 10.45-11.00, före damernas skiathlon. ca 15 min 25 februari ca 13.05-13.30, efter damernas och före ca $30 \mathrm{~min}$ herrarnas skiathlon.

25 februari ca $14.55-16.30$, efter herrarnas skiathlon 28 februari ca 13.50-14.15, efter damernas $10 \mathrm{~km}$ 1 mars ca $14.10-15.15$, efter herrarnas $15 \mathrm{~km}$ 4 mars ca 15.00-16.15, efter damernas $30 \mathrm{~km}$ 5 mars ca $15.40-16.10$, efter herrarnas $50 \mathrm{~km}$ ca $60 \mathrm{~min}$

ca $25 \mathrm{~min}$

ca $60 \mathrm{~min}$

ca $60 \mathrm{~min}$

ca $30 \mathrm{~min}$

\section{Litteratur}

Adelswärd, Viveka, 1989: Laughter and dialogue. The social significance of laughter in institutional discourse. I: Nordic Journal of Linguistics 12(2). S. 107-136.

Adelswärd, Viveka, 1995: Institutionella samtal - struktur, moral och rationalitet. I: Folkmålsstudier 36. S. 109-139.

Baxter, Judith, 2003: Positioning gender in discourse. A feminist methodology. Basingstoke: Palgrave Macmillan.

Billig, Michael, 2005: Laughter and ridicule. Towards a social critique of humour. (Theory, culture \& society.) London: SAGE.

Billig, Michael, 2009: Violent racist jokes. I: Sharon Lockyer \& Michael Pickering (red.): Beyond a joke: the limits of humour. Basingstoke: Palgrave Macmillan. S. 27-46.

Branting, Stina, 2016: Kvinnliga sportjournalister vill bryta manliga revir. I:

Idrottsforskning.se. http://www.idrottsforskning.se/kvinnliga-sportjournalister-villbryta-manliga-revir/ [hämtad 20.12.2017].

Brown, Penelope \& Levinson Stephen C., 1987: Politeness: some universals in language usage. (Studies in interactional sociolinguistics 4.) Cambridge: Cambridge Univ. Press.

Butler, Judith, 2007 [1990]: Genustrubbel: feminism och identitetens subversion. Övers. av Suzanne Almqvist. Göteborg: Daidalos.

Chafe, Wallace, 1987: Humor as a disabling mechanism. I: American Behavioral Scientist 30(3). S. 16-25.

Chovanec, Jan, 2017: Interactional humour and spontaneity in TV documentaries. I: Lingua 10. S. 34-49.

Coates, Jennifer, 2014: Gender and humor in everyday conversation. I: Delia Chiaro \& Raffaella Baccolini (red.): Gender and humor. Interdisciplinary and international perspectives. New York/London: Routledge. S. 147-164.

Davies, Catherine E., 2017: Sociolinguistic approaches to humor. I: Salvatore Attardo (red.): The Routledge handbook of language and humor. New York, NY: Routledge. S. 472-488.

Edström, Maria, 2001: Gränser för kön i TV: Bland boxardöttrar och IT-killar. I: Kerstin Nordenstam \& Kerstin Norén (red.): Språk, kön och kultur. Rapport från fjärde nor- 
diska konferensen om språk och kön, Göteborg den 6-7 oktober 2000. Göteborg: Institutionen för svenska språket, Göteborgs universitet. S. 85-94.

Fairclough, Norman, 2001: Language and power. 2:a upplagan. (Language in social life series 99-0874483-6.) Harlow: Longman.

Foucault, Michel, 1989: The archaeology of knowledge. London: Routledge.

Foucault, Michel, 1993: Diskursens ordning: installationsföreläsning vid Collège de France den 2 december 1970. Övers. av Mats Rosengren. Stockholm: Symposion.

Goffman, Erving, 2005: Interaction ritual. Essays in face-to-face behavior. New Brunswick, N.J.: Aldine Transaction.

Gomard, Kirsten, 2001: Negotiating competence and gender. An analysis of televised political debates in Denmark. I: Anne Krogstad \& Kirsten Gomard (red.): Instead of the ideal debate. Doing politics and doing gender in Nordic political campaign discourse. Århus: Aarhus University Press. S. 60-96.

Gunnarsson, Britt-Louise, 2002: »Style of success» i en mansdominerad miljö. Analys av kvinnliga strategier vid ett doktorandseminarium. I: Per Linell \& Karin Aronsson (red.): Jagen och rösterna: Goffman, Viveka \& samtalet. Texter till Viveka Adelswärd den 17 mars 2002. (SIC 42.) Linköping: Tema Kommunikation, Linköpings universitet. S. 251-263.

Hay, Jennifer, 1995: Gender and humour: Beyond a joke. Wellington: Victoria University of Wellington.

Hay, Jennifer, 2000: Functions of humor in the conversations of men and women. I: Journal of pragmatics 32(6). S. 709-742.

Hilmersson, Eric, 2017: Ett folkkärt radarpar som guidar i skidspåret. I: Göteborgs-Posten, 25 februari. S. 76.

Holmes, Janet, 2000: Doing collegiality and keeping control at work. Small talk in government departments. I: Justine Coupland (red.): Small talk. (Language in social life series.) Harlow: Longman. S. 32-61.

Holmes, Janet \& Stubbe, Maria, 2003: »Feminine» workplaces. Stereotype and reality. I: Janet Holmes \& Miriam Meyerhoff (red.): The Handbook of Language and Gender. Oxford: Blackwell. S. 572-599.

Hutchby, Ian, 2006: Media talk. Conversation analysis and the study of broadcasting. Maidenhead: Open University Press.

Hutchby, Ian \& Wooffitt, Robin, 2008: Conversation analysis. 2:a upplagan. Cambridge: Polity.

Jönsson, Åsa Edlund, 2018: En jämställd sportbevakning - en publik framgång. I: SVT Sport-bloggen. 8 mars . https://blogg.svt.se/svtsport/en-j\%c3\%a4mst\%c3\%a4lldsportbevakning-en-publik-framg\%c3\%a5ng/ [hämtad 8.3.2018].

Jönsson, Åsa Edlund, 2019: En jämställd sportbevakning har bara vinnare. I: SVT Sport-bloggen. 20 februari. https://blogg.svt.se/svtsport/en-j\%c3\%a4mst\%c3\%a4lldsportbevakning-har-bara-vinnare/ [hämtad 4.12.2019].

Kotthoff, Helga, 1996: Impoliteness and conversational joking. On relational politics. I: Folia Linguistica 30. S. 299-325.

Kotthoff, Helga, 1997: The interactional achievement of expert status. Creating asymmetries by "Teaching conversational lectures" in TV discussions. I: Helga Kotthoff \& Ruth Wodak (red.): Communicating gender in context. Amsterdam/Philadelphia: Benjamins. S. 139-178. 


\section{Hanna Söderlund}

Kotthoff, Helga, 2006: Gender and humor: The state of the art. I: Journal of Pragmatics 38(1). S. 4-25.

Kärnebro, Katarina, 2013: Plugga stenhårt eller vara rolig? Normer om språk, kön och skolarbete i identitetsskapande språkpraktiker på fordonsprogrammet. Umeå: Genusforskarskolan, Institutionen för språkstudier, Umeå universitet.

Lampert, Martin D. \& Ervin-Tripp, Susan M., 2006: Teasing and self-directed joking among male and female friends. I: Journal of Pragmatics 38(1). S. 51-72.

Landqvist, Håkan, 2001: Råd och ruelse. Moral och samtalsstrategier i Giftinformationscentralens telefonrådgivning. (Skrifter utgivna av Institutionen för nordiska språk vid Uppsala universitet 55.) Uppsala.

Markula, Pirkko, 2009: Olympic women and the media. International Perspectives. (Global culture and sport.) Basingstoke: Palgrave Macmillan.

Martinec, Radan, 2001: Interpersonal resources in action. I: Semiotica 135(1). S. 117-146.

Messner, Michael A., 2007: Out of play: critical essays on gender and sport. Albany, NY: State University of New York Press.

Mills, Brett, 2011: The guardians of the general interest. Discourses of knowledge in QI. I: Television \& New Media 12. S. 136-153.

Mullany, Louise, 2002. "I don't think you want me to get a word in edgeways do you John?" Re-assessing (im)politeness, language and gender in political broadcast interviews. I: English Studies: Working Papers on the Web 3. https://extra.shu.ac.uk/ wpw/politeness/mullany.htm.

Norrby, Catrin, 2014: Samtalsanalys: så gör vi när vi pratar med varandra. 3:e upplagan. Lund: Studentlitteratur.

Norrick, Neal R., 1993: Conversational joking. Humor in everyday talk. Bloomington, Ind.: Indiana University Press.

Nylund, Mats, 2000: Iscensatt interaktion. Strukturer och strategier i politiska mediesamtal. (Skrifter utgivna av Svenska litteratursällskapet i Finland 622.) Helsingfors: Svenska litteratursällskapet i Finland.

Ohlsson, Maria, 2003: Språkbruk, skämt och kön. Teoretiska modeller och sociolingvistiska tillämpningar. (Skrifter utgivna av Institutionen för nordiska språk vid Uppsala universitet 61.) Uppsala: Uppsala universitet.

Pfister, Gertrud, 2010: Women in sport. Gender relations and future perspectives. I: Sport in Society 13(2). S. 234-248.

Poggi, Isabella, 2007: Mind, hands, face and body. A goal and belief view of multimodal communication. Berlin: Weidler.

Purdie, Susan, 1993: Comedy: the mastery of discourse. Hemel Hempstead: Harvester Wheatsheaf.

Sacks, Harvey, 1974: An analysis of the course of a joke's telling. I: Richard Bauman \& Joel Sherzer (red.): Explorations in the ethnography of speaking. London: Cambridge University Press. S. 337-353.

Söderlund, Hanna, 2016: »Jättekul att det är så många tjejer här ikväll.» En interaktionell studie om humor och kön i tv-programmet Parlamentet. Umeå: Umeå universitet.

Tolvhed, Helena, 2008: Nationen på spel. Kropp, kön och svenskhet i populärpressens representationer av olympiska spel 1948-1972. (Serie akademi 11.) Umeå: h:ström - Text \& kultur.

Trouvain, Jürgen \& Truong, Khiet P., 2017: Laughter. I: Salvatore Attardo (red.): The Routledge Handbook of Language and Humor. New York, NY: Routledge. S. 340-355. Tsakona, Villy, 2017: Intertextuality and/in political jokes. I: Lingua 9. S. 1-15. 